\title{
THE EFFECT OF REPEATED ADMINISTRATION OF HALOTHANE ON THE LIVERS OF HEALTHY MONKEYS
}

\author{
Shimley A. Fleming, B.A., M.D., F.F.A.R.C.S., " and W. G. C. Bearcroft, M.B. $\dagger$
}

TrE RECENT CONTROVERSY concerning the role of halothane in the production of hepatic necrosis is difficult to resolve by the study of human patients. Rarely if ever can other possible hepatotoxic factors related to disease or treatment be completely excluded, and a controlled experiment in man designed to test the hepatotoxicity of the drug is impossible.

Several observers have suggested that halothane produces a hepatic lesion in man similar to that associated with fulminating viral hepatitis. ${ }^{1-8}$ It has been pointed out that typically the hepatic necrosis which has been attributed to halothane has not occurred after a single exposure, but after a second or subsequent exposure to the drug following a rest period, suggesting that the injury may be the result of sensitization of the liver cell to halothane.

An experiment was designed to test the effect of repeated exposure to halothane on the livers of healthy Patas monkeys, and to compare any hepatic lesions so produced with those commonly associated with viral hepatitis in the same species.

\section{METHOD}

Four healthy Patas monkeys, native to West Africa, were used as subjects. Preliminary liver biopsies were done on each animal before exposure to halothane. Once each week for ten weeks the animals were anaesthetized for one hour with halothane vaporized in oxygen. Several days following each halothane anaesthetic a liver biopsy was done under ether anaesthesia which lasted less than one minute, and blood was taken for transaminase determinations.

The animals were anaesthetized by means of an M.I.E.t Infant Set with a mask and open-end reservoir bag, without an absorber. Halothane and oxygen were delivered from the open circuit of a Boyle's machine with a Fluotec vaporizer in series. A flow of five litres per minute was used throughout the first five sessions. During the last five sessions the five-litre flow was used for the first five minutes and then reduced to four litres per minute for the balance of the hour, since it was evident that these small monkeys did not require a greater flow.

The animals were held by the limbs and the back of the neck during induction with three per cent halothane. Induction time was one minute or less. The animals breathed spontaneously, and the concentration of halothane was reduced if there was evidence of respiratory depression.

-Department of Anaesthesia, University of Lagos Medical School.

tWest African Council Medical Research Laboratory, Lagos, Nigeria.

$\ddagger$ Medical and Industrial Equipment Co., London, England.

247

Can. Anaes. Soc. J., vol. 13, no. 3, May, 1966 


\section{RESULTS}

The results in each of the four animals are shown in the protocols. In no instance was a lesion evident in the biopsies of the liver which could be attributed to halothane; neither was there any variation in the blood levels of the serum glutamic-oxalic transaminase or glutamic-pyruvic transaminase which would suggest hepatic destruction.

One of the animals (Patos 517) suffered circulatory arrest on seven occasions during halothane anaesthesia and once during the brief ether anaesthesia required for liver biopsy. On each occasion the animal was resuscitated by artificial respiration and external cardiac compression, and in each instance awakened promptly on termination of the anaesthetic.

Two of the animals (502 and 503) contracted an intercurrent infection with massive diarrhoea to which these animals are subject. They were not given antibiotics because it would then have been impossible to attribute any subsequent hepatic damage to the halothane alone, and both died within the week following the ninth exposure to balothane. Necropsy showed no hepatic necrosis in either case, and in neither case is there any suggestion that halothane contributed to the deaths.

Protocol: Patas 502 (remale, 2 Lbs.)

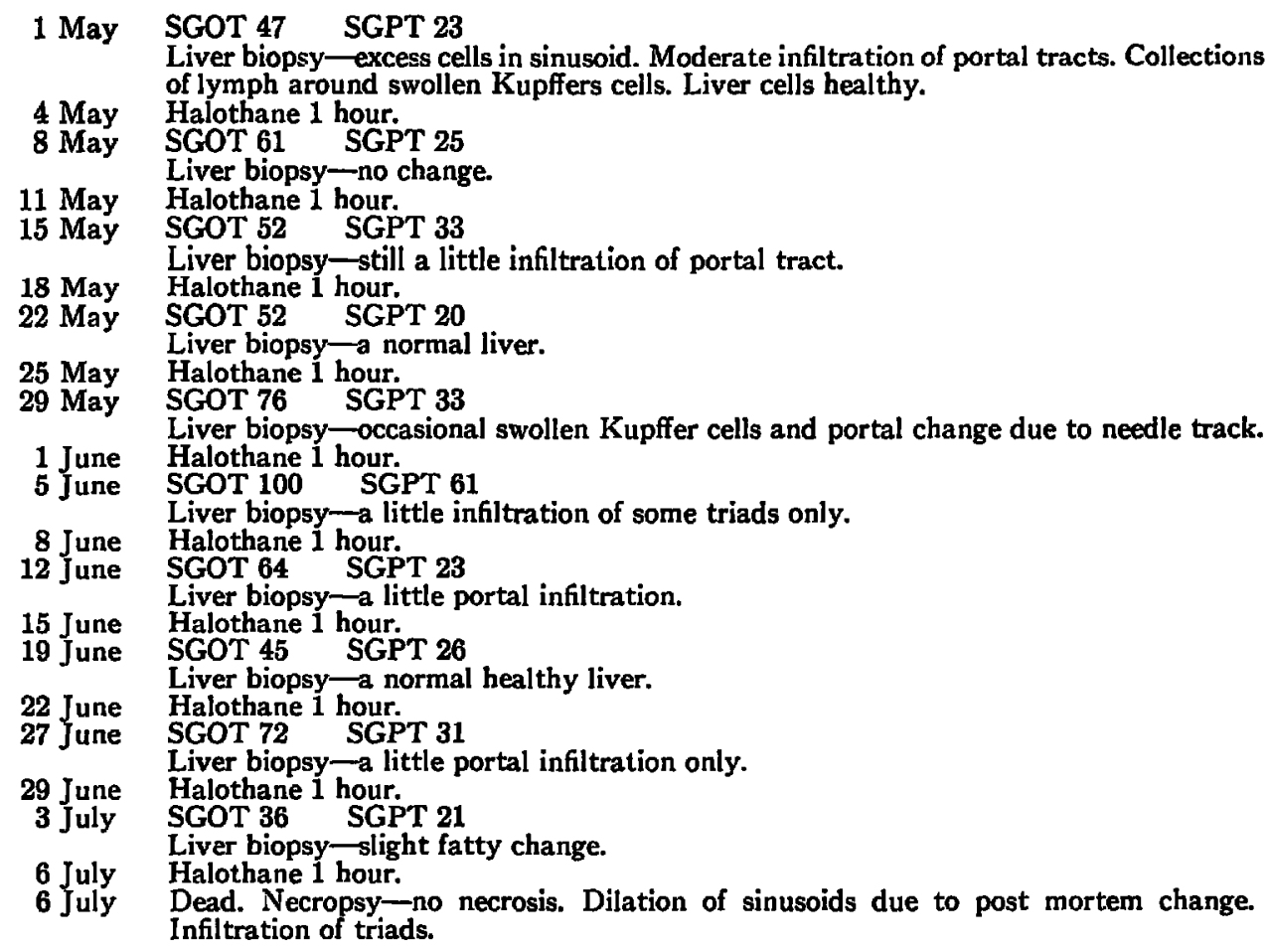

Clinically small animal. Always awakened quite rapidly. Easy to anaesthetize. On last occasion looked very ill and died same day. 
Protocol: Patas 503 (Male, 2 lbs.)

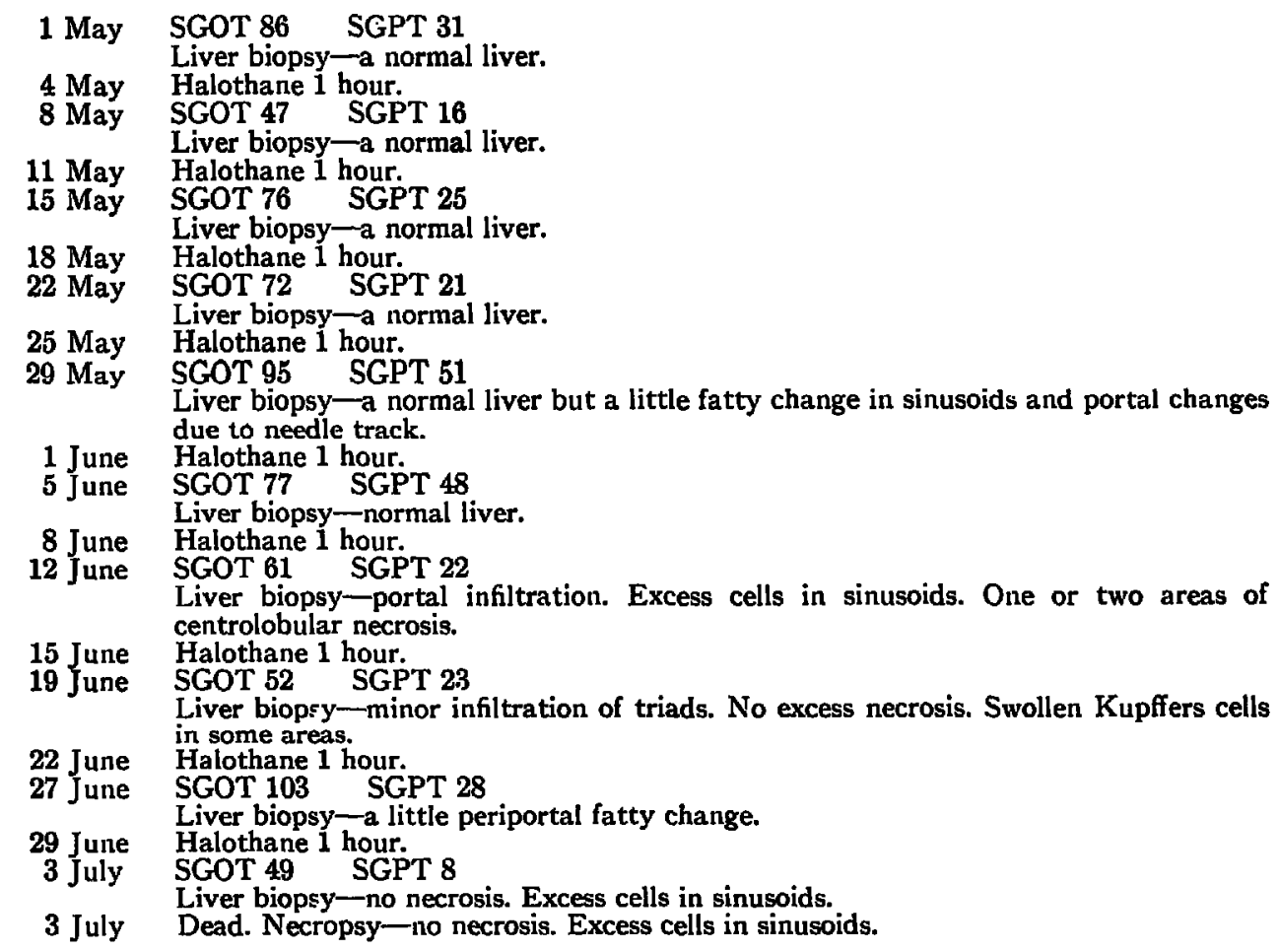

Protocol: Patas 516 (Male, $3 \frac{1}{2}$ LBS.)

1 May SGOT 44 SGPT 21

4 Liver biopsy-a normal liver.

4 May Halothane 1 hour.
8 May
SGOT 38 SGPT 16

Liver biopsy-one focus of infiltration.

11 May Halothane 1 hour.
15 May

Liver biopsy-a normal liver.

18 May Halothane 1 hour.

22 May SGOT 50 SGPT 16

25 May Liver biopsy - a normal liver.

29 May SGOT 73 1 SGPT 21

1 June Liver biopsy-no significant change.

5 June SGOT 12 SGPT 15

Liver biopsy-a normal liver.

8 June Halothane 1 hour.
12 June

Liver biopsy-a normal liver.

15 June Halothane 1 hour.

19 June SGOT 39 SGPT 14

22 June Hiver biopsy-degeneration and infiltration of triads due to adjacent needle track.

27 June SGOT 82 SGPT 16

29 June Hiver biopsy-portal changes due to needle tracks.

3 July SGOT 44 1 SGPT 14

Liver biopsy-no changes. 
6 July Halothane 1 hour.

10 July SGOT 58 SGPT 22

Liver biopsy-no necrosis but some portal infiltration.

Clinincally lively and sometimes hard to catch.

Protocol: Patas 517 (female, $3 \frac{1}{2}$ LBS.)

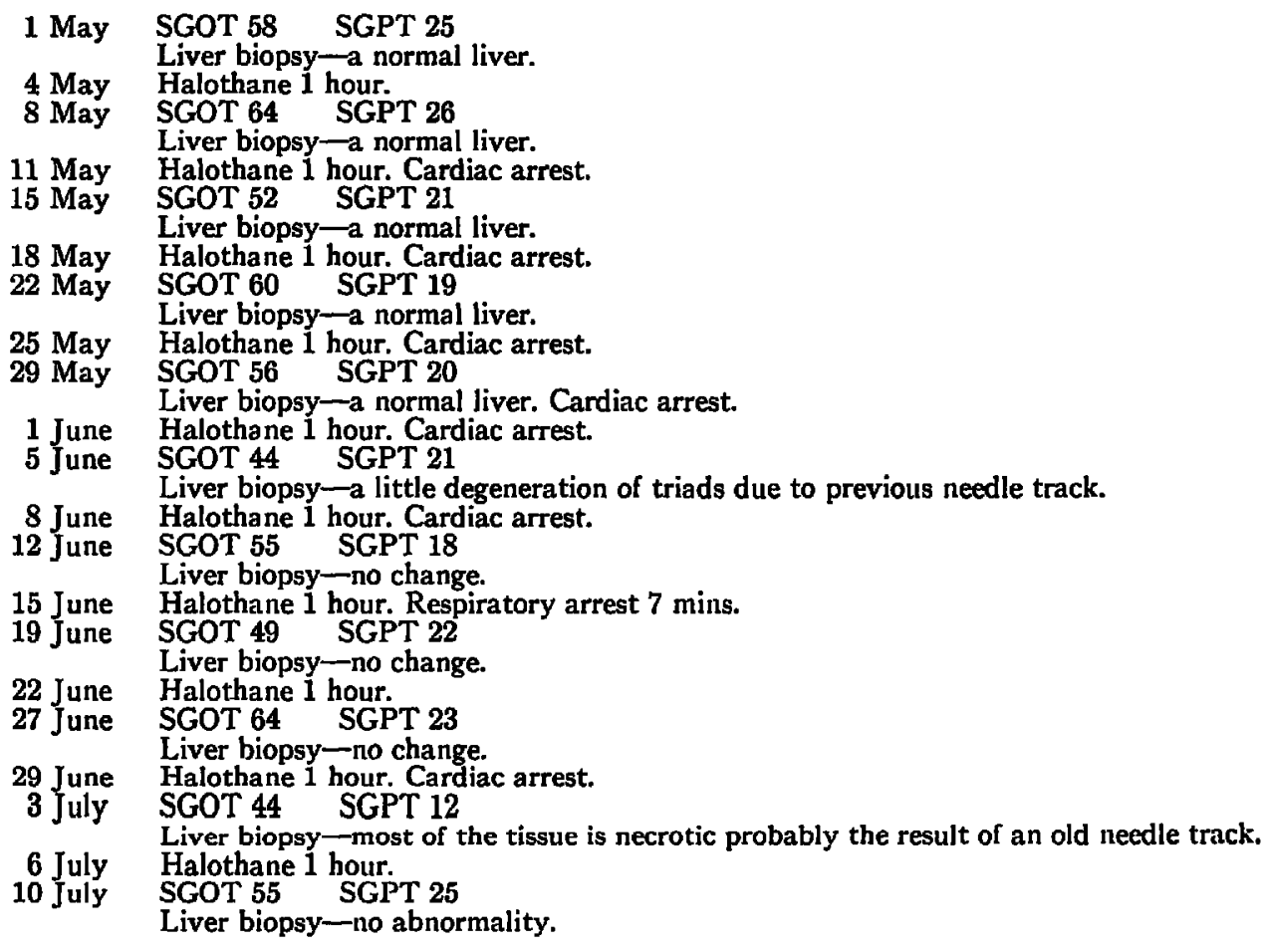

Clinically a most difficult animal to manage. Always awakened rapidly. Arrest occurred suddenly with cessation of respiration, and heart beat could not be felt. Inflation with oxygen and pressure over precordium always resuscitated the animal successfully.

\section{Discussion}

Since all observers are agreed that the incidence of hepatic failure in any way associated with balothane anaesthesia in man is very small, no general conclusions can be drawn from the results of the present experiment because of the small number of animals involved. It is evident from our results however, that halothane is not a specific hepatotoxin in the monkey.

\section{RÉsUMÉ}

Plusieurs observateurs ont émis l'opinion que l'halothane produit chez l'homme une lésion hépatique semblable à celle qui survient à la suite d'une hépatite virale suraigue; de plus, il a été signalé que cette nécrose hépatique typique qui a été attribuée à l'halothane n'est pas survenue à la suite d'une seule administration d'halothane, mais après une deuxième administration de ce médicament précédée d'une période de repos. 
Nous avons établi un procédé expérimental pour étudier l'effet de plusieurs administrations d'halothane des des singes Patas et pour comparer toutes les lésions produites à celles observées ordinairement à la suite d'hépatite virale sur la même sorte d'animal.

Durant dix semaines, à toutes les semaines, durant une heure, nous avons pratiqué une anesthésie à l'halothane avec oxygène sur quatre singes en bonne santé. Entre les administrations d'halothane, nous avons fait des biopsies hépatiques sous anesthésie à l'ether; les taux sanguins de SGOT et de SGPT étaient recherchés. Dans aucun cas, nous avons dépisté une lésion hépatique et, à l'autopsie, nous n'avons trouvé de nécrose hépatique, chez deux sujets qui sont morts d'infection intercurrente.

\section{ACKNOWLEDGMENT}

The halothane used in this study was generously supplied by Imperial Chemical Pharmaceuticals, Ltd.

\section{REFERENCES}

1. Lindenbaum, J. \& Lenger, E. Hepatic Necrosis Associated with Halothane Anaesthesia. New Eng. J. Med. 268: 525 (1963).

2. Tycstrup, N. Halothane Hepatitis. Lancet it: 466 (1963).

3. Srenrock, S. Halothane and the Liver. Proc. Roy. Soc. Med. 57 : 305 (1964). 